\title{
KIDNAPPING IN NIGERIA: A SOCIAL THREAT TO EDUCATIONAL INSTITUTIONS, HUMAN EXISTENCE AND UNITY
}

\author{
Peter C. Ekechukwu' ${ }^{1}$ and Prof. S. D. Osaat ${ }^{2}$ \\ ${ }^{1}$ Department of Educational Foundations, Faculty of Education University of Port Harcourt, \\ Rivers State \\ Email: peter_chizor@yahoo.com; Tel: 08063217819 \\ ${ }^{2}$ Department of Educational Foundations, Faculty of Education, University of Port Harcourt, \\ Rivers State \\ Email: osaatsundan@gmail.com
}

Cite this article:

Peter C.E., Osaat S.D. (2021), Kidnapping in Nigeria: A Social Threat to Educational Institutions, Human Existence and Unity. British Journal of Education, Learning and Development Psychology 4(1), 46-58. DOI: 10.52589/BJELDP/TFA8OS WE.

\section{Manuscript History}

Received: 22 March 2021

Accepted: 17 April 2021

Published: 27 April 2021

Copyright $(92020$ The Author(s). This is an Open Access article distributed under the terms of Creative Commons AttributionNonCommercialNoDerivatives 4.0 International (CC BY-NC-ND 4.0), which permits anyone to share, use, reproduce and redistribute in any medium, provided the original author and source are credited.
ABSTRACT: This paper examined the problem of kidnapping and its consequences in Nigeria. Kidnapping has the potential of creating social tension, psychological trauma (mental and emotional problems), insecurity, untimely death and others in the society. It has been observed and identified that kidnapping is not a new crime in Nigeria and other countries of the world. But the apparent problem of kidnapping is the current growth rate in all parts of the country and the benefits the perpetrators are deriving from this criminal activity. In this study, some challenges were identified. They include: poverty, unemployment, politics and religion. The mode of kidnappers' operations have been identified and its prevalence, apart from the causes attributed to the laxity in the implementation process to prosecute the offenders. As a result of these findings, it is suggested that the issue of ransom payment by the families/relatives of the victims to kidnappers should be seriously condemned. Government on their part, should endeavour to create employment for the teeming population of youths as this will help to reduce the proliferation of kidnappers. Security agents should be well equipped with sophisticated guns to wage war against kidnappers. This will no doubt help to restore peace and security in the country.

KEYWORDS: Kidnapping, Social Threat, Human Existence, Worthy, Multicultural, Religion. 


\section{INTRODUCTION}

Among other criminal cases in Nigeria, kidnapping appears to be one of the most technical and most lucrative in nature, considering the fact that a lot of people are involved unannounced. Kidnappers have a powerful mode of operation which creates fear in individuals because they are uncertain of the next person to be kidnapped. The operators of armed robbery can kidnap immediate family members and divulge all round information about whoever is their target. Kidnapping is not new in Nigeria and is one of the challenges facing the country at present. Though it takes place in all parts of the country, it is most rampant in the South East and South South because of oil business with foreigners.

In recent time, apart from the Boko Haram and Fulani herdsmen terrorism, attention has been turned to the issue of kidnapping and stringent measures have been taken to tackle the menace. Both National and International bodies are coming together to see if the incidence can be curbed. Many engage in kidnapping business for different purposes and missions. Some are politically masterminded, especially among political opponents. Some do it for ritual sacrifice; that is, in situations where the kidnapped persons are never seen again even after huge ransoms are paid. Some engage in this heinous crime solely for the sake of money; in this case, the victims are released after the payment of the agreed ransom. In all, kidnapping can be grouped according to motives into: political kidnapping, kidnapping for marriage, ritual kidnapping and monetary kidnapping.

Investigations have shown that ordinary citizens participate in this atrocious crime in order to fill their pockets, usually the youths employed by rich men who conduct kidnapping as a modern business. They target rich families and sometimes demand colossal amounts of money as ransom. Also, it has been traced among community leaders and religious leaders who are in the business of divulging information with the aim of receiving their share after the deal. This has raised suspense among Nigerians about who to trust or confide in.

Since kidnapping is on the increase in Nigeria, there is a corresponding increase in the level of insecurity in the country. The Government and their security agents ranging from police, military personnel and special anti-robbery squad (SARS) have not achieved considerable results, and many security personnel have been killed by kidnappers who are sophisticatedly equipped. Most often, the security agents meet kidnappers unprepared and considering the fact that the kind of guns these security officers possess are inferior, they stand the risk of losing their lives. Yet, it is within the jurisdiction of the government to make provision for the security of its citizenry. It is no longer an exaggeration to say that the Nigerian police are poorly trained and poorly equipped. And to worsen the situation, the government of today appears to have a mission different from the security of the people. Many have been raped, traumatized and killed without receiving any help from the government (Shuaibu, 2015).

Since it is obvious that security in Nigeria is porous, it becomes imperative for all persons to protect themselves and be vigilant at all times. People in churches, mosques, markets, schools and homes, as well as the highway motorists, are susceptible to this menace and they should try - as a matter of urgency - to pray to God for divine security and intervention. 


\section{Concept of Kidnapping}

So many definitions have been given to kidnapping due to peoples' diverse views and opinions. According to Inyang and Abraham (2013), kidnapping is defined as "the forcible seizure, taking away and unlawful detention of a person against his/her will'. In another definition, Fage and Alabi (2017) presented kidnapping as the "forceful or fraudulent abduction of an individual or a group of individuals for reasons ranging from economic, political and religious to (struggle for) self-determination". In agreement with the two definitions above, kidnapping is usually motivated by financial gains or political benefits. Thus, opportunists or regular criminals as well as political opponents can resort to kidnapping in order to illegally obtain economic benefits or have their demands granted. In many cases, kidnapping is a business involving a demand for ransom, which may vary considerably depending on the victim's personal status.

Likewise, Uzorma and Nwanegbo-Ben (2014) defined kidnapping as the "act of seizing and detaining or carrying away a person by unlawful force or by fraud, and often with a demand for ransom". For an act to be deemed kidnapping, it must involve coercive movement of a victim from one place to another. The detention or seizure of that person-be it a child or an adult - is for a period of time, depending on the willingness of the relatives to respond positively to the negotiations. In most cases, the victims' eyes are blindfolded so that they cannot see or locate the place of detention. Many are detained in places far away from their families. In their forceful movement, a lot of gunshots may be released into the air to create fear and tension, especially in the victim who would be dragged without his consent. Consequently, resistance, struggling and refusal to obey and follow the kidnappers have led to the untimely death of some victims. The perpetrators are often tempted to shoot sporadically for safety in order to accomplish the mission, not minding who gets affected. From the foregoing, there is no best way of defining kidnapping. However, in a nutshell, kidnapping refers to the abduction and captivity of a person, typically to obtain a ransom. Sometimes, kidnappers hold their captives longer in order to demand more ransom from the victims' relatives or friends. Some families go as far as borrowing money from outsiders or selling their properties in order to save the lives of their beloved ones. The danger of not responding immediately could lead to the untimely death of the victim. Many have died during the time of torture, especially those with health challenges. Inyang and Abraham (2013) added that it is allegedly regarded as a restriction of someone's liberty, which violates the provision of freedom of movement as stipulated in the constitution of the Federal Republic of Nigeria, where every other law takes its root.

\section{Kidnapping as a Worldwide Experience}

Kidnapping is a global phenomenon; every part of the world has its share of this menace. America, Mexico and other parts of the world are doing as much as they can to ensure that kidnappers are captured and dealt with, and that kidnapping is completely eradicated.

The rates of kidnapping in Europe, North America and South America are attracting worldwide attention. The practice of kidnapping has become quite lucrative for some and there are criminal groups that have made it their business model. Mexico has its experience especially with its history of drug-related violence and police corruption; kidnapping is an old story. According to the U.S. Department of State, Mexico suffered an estimated 105,685 kidnapping 
cases in 2012 and in 2013, the number increased tremendously to 131,946, the highest number ever recorded (Schuller 1985).

Similar case of kidnapping remains a challenge to the United States. The disappearance of children in the country is not unheard of either, and such is a problem that the police and other agencies are working relentlessly to address. According to the National Centre for Missing \& Exploited Children, roughly 800,000 children are reported missing annually in the country (Freeman, 2006).

In most cases, kidnapping seems to make very little or no sense. One example is an incident that happened in the United Kingdom in which a woman kidnapped her own daughter. According to the Sun, "Karen Mathew was jailed for eight years for her part in faking the kidnap of her own daughter in 2008. There are so many cases of kidnapping involving mothers, fathers, children and other close relations. The question that many asked was, why would a mother kidnap her own daughter? What could have possibly inspired her to do such an abominable act. The answer remains that she intentionally committed the crime for the money involved. In the above case, she purposely did it so that she could claim the $\$ 50,000$ pounds reward offered by the government for finding Sharion. She planned to share the money with her accomplice, Michael Donovan by name, who was a relative (Freeman, 2006).

According to the Offender Management Caseload Statistics, the UK recorded about 57 convicted kidnapping cases between 2007 and 2008. Also, in some countries, kidnapping has affected mainly those who occupy government positions. The son of the former president of Slovakia was once kidnapped. In August of 1995, Michal Kovar Jr., whose father was the president of newly independent Slovakia, was stopped in his car by armed men who handcuffed him, forced him to drink two bottles of whisky, and then drove him to an unknown destination (The Economist, 2017). It is sometimes said that corruption can lead to kidnapping. Somalia, which is one of the most corrupt countries in the world, unfortunately has her fair share of experience with this problem. According to a BBC news report, a German nurse with the international committee of the Red Cross (ICRC) has been kidnapped in Somalia's capital Mogadishu, the aid group says.

\section{Causes of Kidnapping in Nigeria}

Kidnapping, as a heinous crime, is a complex issue. That is why both scholars and concerned individuals have engaged in intense speculations and investigations or studies, so as to know the various reasons and causes of kidnapping. Hazen and Horner (2007) noted that people commit this crime for two obvious reasons which are: political bargaining and economic gains. These two aspects give a broad and vivid classification of kidnapping in order to clearly understand the underlying factors of the menace, especially regarding the idea of ransom. However, apart from these two broad reasons stated above, many have been kidnapped and abducted by criminals for different reasons and intentions, which include illicit intercourse, rape, selling of human parts for ritual sacrifice, political revenge, slavery, ransom-begging, marriage, murder or assassination, sale, unlawful activities, and for other purposes (NCRB, 2014).

Considering the type of kidnapping recently experienced in Nigeria, it is obvious that unemployment is a major cause of kidnapping. Some frustrated graduates, after searching for jobs for up to three or more years, decide to engage in this atrocity for the sole aim of survival. 
Ibrahim and Mukhar (2016) maintained that lack of available employment opportunity among the youths also plays a fundamental role in the rise of kidnapping. Similarly, Inyang and Abraham (2016) observed that Nigeria has a large number of adolescents living and making a living on the streets without any help from the government and besides, the government is not interested in helping. The fact that they are neglected gives them the morale to terrorize the society without any remorse.

In Nigeria and many other developing countries in Africa and Asia, the political factor is another cause of kidnapping. Many politicians engage the services of kidnappers to deal with their political opponents and their political power, popularity and economic muscles. Zannoni (2003) called this type "political kidnapping" where the overall objective is to promote the political aims of a particular political group or movement. In this case, a ransom is usually demanded to obtain money for the group in order to fund their campaign and other activities. This is in line with Catlin Group (2012) who added that political extremists use kidnapping as a political weapon and as a means of financing their activities.

Closely related to unemployment is poverty, which has ravaged the masses. Nigeria has the highest number of people in Africa living below average lives. Zannoni (2003) categorized people compelled by poverty to get involved in kidnapping as criminal kidnappers, whose main motive is to obtain ransoms from families or business enterprises for survival. In this type of kidnapping, any person with or without criminal intention can join especially as it appears to be profitable, not minding the mortal consequences. Many in this category are not professionals, meaning that they are not well trained and equipped; they are only being led by trained ones. They get easily arrested by the security personnel who are on patrol exercise. Poverty is on the increase because those at the corridors of power are yet to consider the plight of the masses; hence, the disparity between the rich and the poor keeps growing day by day. This economic deprivation has planted the seeds of kidnapping as a way of getting moneyby these poor youths - from various communities. The poor masses, out of resentment and in a bid to get their own share of the national cake, decide to terrorize the rich men even when the legal implications are grievous. Religion in Nigeria is a threat to the peaceful existence of the country. It is obvious that two religions are practised in Nigeria but these two religions have never been in harmony due to issues of beliefs. Dodo (2010) noted that the Islamic religion has never been in agreement with the Christian religion. Each religious group is making frantic efforts to be on top, especially the Islamic religion. In most cases, Christians are kidnapped and killed secretly just to reduce their number. Severally, sudden disappearance of Christians living in the Northern part of Nigeria raises tension.

Boko Haram's kidnappings are both political and religious, according to their leaders and the Nigerian government.

\section{Kidnappers' Targets}

\section{Politicians:}

As already pointed out, kidnapping is not a new problem in Nigeria, and it is one of the biggest challenges. The country faces many problems, including unemployment, corruption and poverty. But what bothers many people is, who are the targets of kidnappers? According to Nseabasi (2009), the top kidnapping operations are masterminded by government officials, opposition groups, unrewarded or uncompensated members of election rigging, militant groups 
and others. This is prominent especially during political elections, as often observed. The ambitious political candidates aspiring for one position or the other tend to kidnap their opponents as a way of silencing them or as a measure to drain their financial muscles. In this case, after the victim pays the ransom, he or she cannot have enough for political campaign. This has been the fate of many political aspirants. So, kidnapping is seen as an instrument for political vendetta and settling of political scores.

\section{Businessmen and Religious Leaders:}

Apart from the politicians, another set of people who are kidnappers' targets are the businessmen. Several cases of businessmen, who were kidnapped, have been recorded recently, in which large sums of money were expected as ransom. This has affected many, especially the importers, who cannot stand on their feet anymore after spending in the hands of the kidnappers. It is unfortunate that the perpetrators of this menace have equally extended their operations to religious leaders. Oftentimes, Pastors, Reverend Fathers and Bishops have been kidnapped. In 2016 and 2017, it was reported that two catholic Reverend Fathers in Orlu Dioceses were kidnapped and huge ransoms were demanded. The same happened in Catholic diocese of Aba where two priests were kidnapped to an unknown destination, though through the prayers of the members, they escaped. It is obvious that kidnappers do not have respect, not even to men of God. The operation is also organized and targeted at foreign workers or contractors working directly for the government. Many foreign contractors, as it stands, find it difficult to receive contracts here in Nigeria, especially the South-South and South East. Due to this experience, the government gives them military men as their security officers.

\section{Tips to Kidnappers:}

It has been observed that many have been affected due to their flamboyant way of life; in situations where one unnecessarily exposes his wealth for people to see. This is rampant among university lecturers, who out of good will, exhibit their wealth to area boys who in turn plan for their kidnapping. Careless talk has equally put many people into this precarious situation. Discussing your wealth and financial activities outside your home can be dangerous because walls have ears. In 2014, a factory worker in Enugu was kidnapped in a beer parlour not minding those who were listening to him. At night of the same day, he was kidnapped.

It is on record that some wealthy men who move about without fear or prejudices normally settle kidnappers from time to time. They know the gangs and their meeting points, and that is why they move about their businesses in the daytime. Those who are ignorant of this secret regularly fall victims of circumstances. This is the extent of intimidation and victimization by kidnappers in the country. They target rich families, politicians and poor people as well; it all depends on the circumstances that lead to the kidnapping. But the major targets are the rich businessmen, as often observed in South Eastern Nigeria.

\section{Kidnappers' Modes of Operation}

The lucrative nature of kidnapping in recent times has made many young people to join the business. This time, there are different groups with different modes of operation. Investigations carried out confirmed that each group has a gang leader and specified operations within its jurisdiction, as assigned by their overall leader in the state. So, a person could be kidnapped by one group today and by tomorrow, another group would kidnap him again. This is why many victims have been kidnapped more than once or twice, though this depends on the information 
received about the victims before their kidnapping. If two or three groups receive the same information by their respective informants, the tendency that more than one group will kidnap the person becomes obvious.

Most of the victims of kidnapping who narrated their experiences made it known that kidnappers' camps are usually lonely zones like deserted bushes, forests or buildings in different villages, where people hardly visit. Anywhere such places are located, they make them their abode and they become danger zones; they are ready to shoot at any person they see within that area. Each group of kidnappers is divided into three 3 teams, namely the tax force, the operation team and the guards. The business of the tax force is to negotiate with the family of the victim on what should be the ransom; the people in this team are mainly the leaders of the gang. The work of the operation team is to kidnap the victims; the people in this group are well trained and fortified with sophisticated guns. During operation, they are willing to kill provided they succeed in their mission. The work of the guards is to keep watch on those already kidnapped. They receive instructions from their gang leader(s) either to release or to kill the victim, depending on the outcome of the negotiation.

Kidnappers do not operate in isolation, they have networks-groups that are strategically positioned in different localities and streets. It has been observed that some street boys belong to kidnapping groups. Their work is to monitor and give accurate information about the rich or businessmen in the street. They study their movements and report regularly to their gang. Some jobless men and women equally serve in this capacity. They roam the streets just for the purpose of investigating some individuals who are well-to-do. Sometimes, you see them in different churches, especially in weddings. Their work is to study who makes the highest donation of money during launching and other project donations.

It is on record that most kidnappers work for politicians who supply them with ammunition during political elections. Those sophisticated arms are never retrieved after elections. In a situation where the guys are not well compensated, they resort to using the arms for kidnapping, armed robbery, etc. Apart from that, those who have specialized in the business go as far as buying their guns secretly, while some get their arms from security agents like the police, military and other armed forces in Nigeria. The idea of holding sophisticated guns equips and prepares them to challenge any opposing force during operations. Most of the kidnapping activities are carried out in a clandestine manner. But in a situation where they are faced with a challenge, they start shooting sporadically either to scare people away or to challenge their opponents, squarely.

According to Ibrahim and Mukhtar (2017), kidnappers make extensive use of phones. Every transaction is through cell phones. During negotiations, numerous sim cards are used and discarded. The idea behind this is to avoid tracking by network companies. Sometimes, kidnappers hold their captives longer in order to demand more from the relatives of the victims. During the process of negotiation, the victims are tortured severely and in the course of the excruciating pains, they desperately appeal to their relatives to respond or agree to the terms of their abductors. In most cases where the ransom is exorbitant, the family resort to selling their properties in order to pay for the release of their loved one. In their networking transaction, negotiations are made at different strategic locations by those in the tax force team.

In their smart nature, once an agreement is reached, they dribble the person coming to supply the money for a longer time and from one place to another, just to make sure that he/she is not 
accompanied by any other individual. Sometimes, the victims die before their release either because of illness or as a result of severe torture.

\section{Effects of Kidnapping on Educational System in Nigeria}

According to Dantala (2014), one of the greatest challenges facing the education industry in Nigeria is kidnapping, which is part of the insecurity issues in the country. The consequences of kidnapping on the Nigerian educational system can be seen in its lack of growth and development. For more than two decades now, it has been observed that educational institutions are the major targets of the kidnappers. The kidnappers see lecturers, proprietors, principals and some school teachers as wealthy men and women in the society. In their conception, education is a lucrative business. Several incidents of kidnapping have been recorded among education personnel. Many university lecturers, school proprietors and principals have been kidnapped at one point or the other. Some paid through their noses as huge ransoms were demanded for their freedom. In most cases, some lost their lives.

Apart from University lecturers and school proprietors/principals, Nigeria has witnessed several cases of kidnapping of school children. The greatest among them is the kidnap of the Chibok girls during President Goodluck Jonathan's regime. Their abduction came as a challenge not just to the federal government but to states, religious bodies and every Nigerian. The federal government spent huge sums of money to effect their release, all to no avail as there was no trace of the kidnappers, let alone the girls. It took some years before some of the girls were released and one could imagine what would have been the experience of their parents throughout these periods. It is on the national papers that cases of kidnapping are increasing day by day without any assurance of a lasting solution.

The effect of kidnapping remains traumatic as the victims pass through excruciating pains. One can imagine what those Chibok girls passed through in the hands of those kidnappers. Adofu and Alpaslan (2018) asserted that kidnapping and other insecurity matters sooner or later will reduce the manpower needed for the growth and development of the nation. Investigations confirmed that there is fear among lecturers and other personnel in the education industry. Due to the ugly experience of kidnapping, many lecturers and teachers have refused to come back to the teaching profession for fear of kidnappers. Some refused to accept transfer letters, especially to those areas where cases of kidnapping are rampant. Some schools are deserted as parents are afraid of sending their children to those schools where kidnappers attacked at one time or the other. Some schools now experience a lack of qualified teachers to handle core subjects, the reason being that the qualified ones cannot afford to lose their lives in the hands of kidnappers.

Furthermore, the money the government spent to fight kidnapping could have been used to provide infrastructural development in the education sector. Also, the school environment is constantly threatened by kidnapping. Ordinarily, for education to be effective, the atmosphere should be peaceful, otherwise the aims and objectives of education, as contained in national policy of education, cannot be achieved. Parents, on the other hand, suffer severe trauma and some die as a result of the shock emanating from the menace of kidnapping.

\section{Effects of Kidnapping in Nigeria}

In all areas, the effects of kidnapping are devastating, no matter the type of kidnapping one encounters. Victims are humiliated and dehumanized irrespective of their age, position, socio- 
economic status, level of education and popularity. The psychological trauma alone can increase the blood pressure of the victim and this can lead to stroke (Kaylor, 2015). Generally, there are grievous effects of kidnapping both on the victims, relatives, associations, community and society at large. The forceful removal of a person traumatizes the victim as well as his/her relatives and friends. Such ugly news creates tension among the relatives who are then given one possible solution to effect the release of the victim. During this period of abduction, the victim loses the contact of his relatives and friends (Orset, 2008).

In most cases, female victims are sexually abused as a result of kidnapping. This act exposes the person to the risk of contracting sexually transmitted diseases. Many ladies get impregnated by the criminals. Any form of resistance or refusal could lead to the death of the victim. This issue of constant rape by kidnappers is an ugly experience female victim cannot forget easily. Some, after their release, conceal that information in order to avoid having a contemptible reputation before their husbands and relatives (Clark, 2004).

It has been severally reported that many victims lose their lives in the hands of kidnappers, without a trace of their corpses. Some lose their lives during the kidnapping operation while some that need medical attention die during severe torture. In some cases, some victims are used for ritual sacrifice by ritualists or politicians. This goes to confirm that kidnapping is carried out for different purposes. Hence, one can imagine what the experience can be when one loses his or her lovely relative. In 2006, such a case happened in Aba, Abia State, where a medical doctor died as a result of carelessness and the hardened nature of most kidnappers. The medical doctor was in charge of Victory Medical Hospital, Aba. In fact, after a long negotiation and payment, upon his release, he was found dead and abandoned in the bush. Nigeria has lost some professionals and notable figures in the hands of kidnappers (Freeman, 2006).

According to Catlin Group (2012), it has been estimated globally that ransom payments could be US\$500 million annually. So, kidnapping is also accompanied with huge economic implications; the Nigerian Government spent billions of Naira to release the Chibok Girls. Money which should have been spent on the masses and development projects is now diverted to payment of ransom to criminals. Similarly, parents and relatives suffer financial distress seeking to borrow money to pay the ransom. This aspect can take a family into abject poverty. This economic implication, according to Clark (2004), is a worldwide experience that has ravaged most developing countries in the world.

Similar to the economic implication of kidnapping is the injury the victims sustain during violent operations or while in detention. Many are hospitalized for adequate treatment after abduction and release. The treatment does not go without corresponding hospital bills. Another consequence of kidnapping is sexual molestation of kidnapped children, especially the underaged victims, who are often subjected to forced marriage with older husbands. This has rendered many young girls useless in 29 countries across Africa and Latin America (Clark, 2004).

In a nutshell, kidnapping leads to insecurity in the country - a situation where the citizens of a nation are not sure of their protection and existence. It is obvious that insecurity is part of corruption in the society. How can one expect development when kidnapping is the order of the day? 


\section{Efforts made by the Government to Curb the Menace}

Kidnapping is on the increase in Nigeria and it is prevalent across the six geopolitical zones. It aggravates the level of insecurity in the country. Both past and present government administrations have never relented in their effort to fight and reduce kidnapping in Nigeria. Though kidnapping takes different forms and names ranging from human trafficking, political assassination to other forms of abduction. "Kidnapping is not new in Nigeria and it is one of the country's major challenges". Nigeria faces problems of unemployment, bribery and corruption. But facts and figures show that the kidnapping frequency in the country is high. In fighting the menace, Nigeria is not alone; both national and international bodies are coming together to see if the incidence can be reduced (Fage \& Alabi, 2017).

Looking at the increasing nature of kidnapping in Nigeria, one begins to wonder if the government is truly fighting kidnapping and other acts of terrorism in the country. Whatever the programme of the government is to fight the menace, it has not yielded tangible results. The anti-terrorism programme that was set up to combat all forms of terrorism has been silenced as there are still cases of Boko Haram insurgency, Fulani herdsmen and Niger Delta militants overpowering the government (Onovo, 2009).

Recently, the inspector general of police announced on the television that a special squad has been trained to face kidnapping in the country. Even the army chief of staff assured the entire country on television that their special anti-terrorism squad has dealt mercilessly with Boko Haram terrorists and there are no hideouts for them anymore. But it has been found out that some of those news are fake. They were designed to impress the masses and to maintain their pride as soldiers. Most of the soldiers sent to Borno and other Boko Haram zones were overpowered and killed in the desert by those hoodlums. Many military personnel may soon be afraid to confront the Boko Haram terrorists. It is on record that thousands of soldiers have been wasted by Boko Haram and Niger Delta militants, who also specialize in kidnapping the foreigners sent for oil exploration in that region.

According to Okoro (2010), unless the government addresses the issue of unemployment, their efforts will be in vain. The unemployed youths must be engaged, otherwise they will continue to be tools in the hands of corrupt politicians. From the look of things, it appears that unemployed graduates are increasing day by day, and this portends grave danger to the society. These youths invariably look for alternative means of survival. The issue of employment now is for politicians and other political heavyweight champions. Until factories and industries are built all over across the nation, employment opportunities will be a mirage.

Shuaibu (2015) posited that poverty has caused many Nigerians to accept kidnapping as a lucrative business. The poverty alleviation programme set up by President Olusegun Obasanjo in 2004 should have settled the case of poverty but it was abandoned along the way. That should have been a grassroot measure to settle the masses living on the mercy of God. Out of selfaggrandizement, each regime has its agenda or programme; hence, the old ones are abandoned. There is no continuity of project execution. This is leadership failure and loss of societal value.

In a nutshell, it can be deduced that the effort of the government is only on paper and not in practice since there is no evidence to confirm their efforts. One thing is to make policy but the policy implementation matters a lot. Some of the policies on terrorism are yet to be 
implemented and the release of kidnappers after being arrested creates suspicion about who to trust in the country.

\section{CONCLUSION}

Kidnapping is still on the increase because the government's effort is not enough to curb the menace. Such human trafficking should not be handled as an ordinary thing, rather it requires drastic measures to jettison it. The six geo-political zones in Nigeria are faced with different versions of kidnapping. In the North East and North West, kidnapping is Boko Haram insurgency and herdsmen attacks. In the Niger Delta region or the South-South and South East, militants have adopted kidnapping as an insurgent strategy to abduct foreigners and to seek ransom to champion their violent movement. The willingness of the government to combat corruption will help to reduce the rate of kidnapping and other criminal activities going on in the country. It is obvious that criminal opportunists also commit kidnapping for ransom. Investigation recently carried out confirmed poverty as a contributory factor in the increase of kidnapping in Nigeria. One can imagine a situation where most of the unemployed youths engage in this business of kidnapping as a means of getting money (ransom) and as a survival strategy. Corruption is strongly connected with kidnapping; politicians use youths as political thugs to kidnap opponents and their family members, and make certain demands.

\section{RECOMMENDATIONS}

In order to address the challenge of kidnapping, there is an urgent need for collective effort of the government, foreign government and non-governmental organizations (NGOs). Communities, families and other vulnerable groups should team up to address the menace. Adequate measures against kidnapping should be taken. These measures require immediate attention. It is further recommended that:

1. There is a greater need for the Nigerian government to revisit poverty alleviation programmes and employment opportunities. This will help to engage the unemployed graduates who feel frustrated in life.

2. For effective combat of kidnapping, the level of laxity in the law implementation process to prosecute offenders should be addressed as urgently as possible. The perpetrators of kidnapping should be arrested for thorough investigation and appropriate punishment, otherwise the menace will still be on the increase.

3. In most cases, kidnappers hide in different villages and localities, there is a need to engage the community leaders, especially the kings, chiefs and other traditional title holders in the fight against kidnapping. They can assist in fishing out kidnappers in their various communities.

4. Non-governmental organizations should also participate in the war against kidnapping in Nigeria and neighbouring states. Their contributions can come through the creation of public awareness either in a form of seminars or orientation programmes. 
5. Anti-terrorism programmes should be made alongside anti-kidnapping programmes in Nigeria.

6. The law enforcement agents such as the police and other security agencies meant for anti-human trafficking, should be adequately trained and equipped with sophisticated ammunition against kidnappers. The training should address how to identify victims and rescue them from the kidnappers without them being hurt.

7. Nigerian constitution should have a provision specifying severe sanctions against kidnappers. The penalties should serve as a deterrent for those already involved and those who may wish to join the business.

8. Religious organizations such as different churches and mosques should constantly preach against kidnapping in their various church programmes. Members should be made to know the consequences of kidnapping as a crime.

9. Educational institutions should offer counseling on how to avoid being kidnapped or offer therapeutic lessons for primary and secondary victims of kidnappings.

10. Poverty alleviation programmes should also be directed towards addressing high incidence of poverty among women and children, who are a vulnerable segment of the population mostly kidnapped by terrorists or insurgents. These people are always trapped by organized criminals.

\section{REFERENCES}

Action on Armed Violence (2013). Mapping efforts against armed violence in Nigeria. Interim Report by the AOAV and National Working Group on Armed Violence (NWGAM).

Catlin Group (2012). Kidnap and ransom today. A report by Catlin Group Limited. London, UK.

Clark, S. (2004). Early marriage and HIV risks in Sub-Saharan Africa. Studies in family planning, 35(3). 149-160. http://www.ncbi.nlm.nih.gov/pubmed/15511059

Dodo, A. W. (2010). The causes and remedies of kidnapping in Nigeria. The Nigerian academic forum. 19(1) 1-4. Retrieved from:

www.globalacademicgroup.com/journals/the Nigerian academic forum (Accessed on 12/08/2019).

Fage, K.S. \& Alabi, D. O. (2017). Nigerian government and politics. Abuja: Basfa Global Concept Ltd.

Freeman, M. (2006). International child abduction effects. Reunite International Child Abduction Centre.

Hazen, J. M. \& Horner, J. (2007). Small arms, armed violence, and insecurity in Nigeria: The Niger Delta in perspective. Geneva: Small Arms Survey

Ibrahim, B. \& Mukhtar, J. I. (2016). Changing pattern of prostitution: An assessment of transnational commercial sex by Nigerian women. European Scientific Journal. 12(2). 81-95.

Inyang, D. J. \& Abrham, U. E. (2013). The social problem of kidnapping and its implications on the socio-economic development of Nigeria: A study of Uyo metropolis. 
Mediternean Journal of Social Sciences, 4(6). 531-544.

Doi:10.5901/mjss.2013.v4n6p531

Kaylor, L. (2015). Psychological impact of human trafficking and sex slavery worldwide: Empowerment and intervention. John Jay College of Criminal Justice, New York, NY.

Okolo, S. (2010). Security challenge in South East and South South, being a speech delivered during South East and South South Security summit organized by National Association of Chamber of Commerce, Industry, Mine and Agriculture (NACCIMA) in Enugu.

Onovo, O. (2010). Security challenge in South East and South South, being a speech delivered during South East and South-South Security Summit organized by National Association of Chamber of Commerce, Industry, Mine and Agriculture (NACCIMA) in Enugu.

Schiller, D. T. (1985). The European experience, in: BM Jenkins (Ed.): Terrorism and personal protection. Boston: Butterworth, pp. 46-63.

Shuaibu, S. S., Salleh, M. A., \& Shehu, A. Y. (2015). The impact of Boko Haram insurgency on Nigerian national security. International Journal of Academic Research in Business and Social Sciences. 5(6). 254-266.

Uzorma, P. N. \& Nwanegbo-Ben, J. (2014). Challenges of hostage-taking and kidnapping in the South-Eastern Nigeria. International Journal of Research in Humanities, Arts and Literature. 2(6), 131-142.

Zannoni, I. E. (2003). Understanding and managing the threat of kidnapping. Retrieved from:

http://securitysa.com/article.asp?pklArticleID=2443\&pklIssueID=333\&pklCategory ID=8 8 accessed on: 11th August, 2016. 